\title{
Teaching Metaphors: Supporting Professional Growth and Shaping Teacher Identity
}

\author{
Kathleen I Harris \\ Correspondence: Kathleen I Harris, School of Education and Applied Social Sciences, Seton Hill University, \\ Greensburg, Pennsylvania, USA.
}

Received: July 22, 2021

Accepted: August 24, 2021

Online Published: August 25, 2021

doi:10.11114/jets.v9i8.5301

URL: https://doi.org/10.11114/jets.v9i8.5301

\begin{abstract}
A phenomenological study was conducted to further a better understanding, and inquire a new awareness, on how metaphors can support professional growth and shape teacher identity for early childhood education students. Examining teaching metaphors might be another strategy for teacher preparation programs to help early childhood education students in identifying their pre-existing values about teaching and learning. Teaching metaphors may guide students to reflect on values and beliefs that make an important impression on their individual teaching journey.
\end{abstract}

Keywords: metaphors, teacher education, teacher identity, professional development

\section{Introduction}

What is the paraphernalia of teaching? What does conceptualizing developmentally appropriate practice entail in an early childhood classroom? How do they become a reflective and culturally responsive practitioners? In the ongoing inquiry surrounding teacher preparation and the professionalization of teaching, early childhood educators are encouraged to become more aware of their own methods and practices (Ryan \& Whitebook, 2012). To be successful, teacher preparation programs should illuminate the connections between professional development and practice as well as those among practice and children's growth, development, and learning (Barbour \& Lash, 2009). In one respect increasing future early childhood teachers' awareness of their implicit belief systems, dispositions, teaching practices, and professional identity involves the metaphors and images they use to define their teaching. Early childhood students should organize the curriculum, instructional strategies, assessment, classrooms, and the ecology of schools using metaphors that they choose intentionally and deliberately. Metaphors reflect education practice; they are dialog-engendering (Badley \& Van Brummelen, 2012). Metaphors, which help students "see" and envision what they haven't seen before, can help educators paint fuller pictures of how they view life in the classroom (Lakoff \& Johnson, 1980). Several studies have been conducted on the importance of metaphors for teaching practices and the use of metaphors in eliciting teachers' beliefs of teaching (Inbar, 1996; Kesen, (2013); Martinez, Sauleda, \& Huber, (2001); Massengill-Shaw \& Mahlois (2008); \& Oxford et. al. (1998). Research findings from these studies may assist educators and teacher preparation programs with supportive and helpful information about teacher beliefs and the importance of using metaphors as a foundation for a deeper understanding of teaching and learning. Metaphors may be valuable images for teachers to consider in guiding their practice and professional development.

\section{Defining the Metaphor}

Metaphors, which are an important part of everyday language (Badley \& Van Brummelen 2012), convey insights by equating one word and another word, object, or idea in order to propose a unique argument for clarity or usage. In a metaphor one object or concept is figuratively equated with another. Metaphors can be powerful emotional tools that promote a shift in perception, offer a new outlook on an old, familiar topic, or conceptualize new information (Noe, 2007). Metaphors act as symbols in which two different ideas or concepts are equated to highlight comparisons (Badley \& Van Brummelen, 2012). In addition, they offer unique opportunities for educators to conceptualize and bring distinctive meaning to situations through imagination (Milton, 2009). Perceptions and thoughts become more vivid and interesting with metaphors (Kesen, 2013). Serving as a lens through which one can view experience in new ways (Lakoff \& Johnson, 1980), a metaphor is not merely a figure of speech but also an essential mechanism of the mind that allows the modeling and reification of prior experiences (Zhao, Coombs, \& Zhou, 2010). Metaphors are often used to allow an individual to explore and understand something abstract or novel; thus, they can help early childhood teachers 
conceptualize their teaching and examine it, revealing their educational values, beliefs, and personal growth (Gillis \& Johnson, 2002).

\subsection{Understanding Metaphors}

Metaphorical thinking involves employing a familiar object or event as a conceptual tool to demonstrate features of a complex situation (MacCormac, 1990). The ability to understand particular metaphors depends on several factors, including past experiences, metaphorical thinking skills, and culture (Noe, 2007). Fundamental to one's search for meaning, metaphors help to make sense of current circumstances and the world (Perry \& Cooper, 2001). The opportunity to adopt the poetic language of metaphor allows pre-service teachers to think about their developing identities in alternate, sometimes simple, highly creative ways. Reflective of personal thoughts and feelings, metaphors provide a vital source for gaining insights into the teaching profession (Inbar, 1996). In addition to mirroring one's own reality, metaphors can facilitate reflection and professional growth (Black \& Halliwell, 2000) and serve as instructional tools for developing a relationship between teaching and learning (Hoban, 2000) and for teacher evaluation (Kemp, 1999).

\subsection{Creating Meaningful Metaphors}

For a metaphor to be compelling and formative, it must be substantive and dynamic (Badley \& Van Brummelen, 2012). When creative metaphors may contain layered meanings, multiple interpretations and associations are possible; thus, grasping a metaphor is often easier than devising one (Noe, 2007). To initiate the flow of creativity, a metaphor-maker may consider sources such as children's picture books, inspirational quotations, sayings, and stories to help select, use, and even reinvent metaphors. Producing a list of metaphors that can illustrate and communicate the circumstances in a narrative is important. Selecting a word or object that is significant to the overall story or message is the first step in creating a metaphor. To help students create metaphors, they can start with simple comparisons. After making a list of nouns, students can choose a word that conveys their teaching style or defines them as a teacher. They should brainstorm and exercise their creativity. Second, students should use imagery to construct a comparison that explains, exemplifies, or contrasts with purpose the nature of the metaphor; they can involve the senses and elaborate. Third, they should continue to build the metaphor by adding specific elements that establish purpose and meaning. They may add other elements or characters to supply meaning and significance, create depth and personal identification; and enhance the quality of writing. Metaphors should nourish and develop metaphor-makers' intellectual independence. For example, they can discuss important extracurricular activities, such as hobbies, sports, or special interests for making connections between passions and their teaching.

\section{Listening to the Inner Voices of Teachers}

Opportunities in studying academic subjects can awaken a sense of self and yield clues to one's identity, but the call to teach comes not only from external encounters. Ultimately, the authentic call comes from the voice of the teacher within, the voice that invites and honors teaching as a calling and vocation (Palmer, 1998). The inner voice, the teacher within, is the voice of dignity and integrity. Listening and paying attention offers an answer to the question "Who am I as a teacher?" How does an early childhood education student, just starting her or his professional development and journey into teaching, attend to and address the voice of the teacher within? One approach to examining aspects of identity is through the use of metaphors (Thomas \& Beauchamp, 2007), which are fundamental to the human quest for knowledge (Mac Cormac, 1985); that is, they are a means for framing and defining experience in order to achieve meaning in one's life (Massengill Shaw \& Mahlios, 2008). Metaphors also have the capacity to lead pre-service early childhood teachers toward greater freedom in their understanding of instruction and curriculum, increasing their creativity (Efron \& Joseph, 2001). Finally, metaphors are often conventional, meaning that they are relevant to culture. In such cases, metaphors are culturally bound, providing windows into different ways in which educators conceptualize personal and teaching experiences.

\section{Using Metaphors in Eliciting Teacher Beliefs and Exploring Professional Identify}

Teacher beliefs have the potential to impact all aspects of pre-service teachers' work in field experiences, including what ideas and concepts they choose to accept or reject and how they teach (Pinnegar, Mangelson, Reed, \& Groves, 2011). Teachers' beliefs, or visions, function as understandings that impact planning for teaching as well as teacher interactions and actions with children, families, and colleagues in and outside the classroom (Hammerness, 2006). Teachers' perceptions, attitudes, dispositions, and beliefs change, and potential changes play a role in how beginning early childhood educators shape the roles they adopt and the professional development of their identities (Kesen, 2013). Identity is related to competence and connectedness, which are both important aspects of the dispositions of good early childhood teachers and essential in the ability to move forward successfully into the chosen vocation (2018).

Metaphors can be used to learn about personal identify, beliefs, dispositions, and conceptions of teaching and learning 
(Massengill Shaw \& Mahlios, 2008). Holt-Reynolds (1992) stated that education students may learn from teacher education courses those things that their teacher-selves tell them they need to know. Using metaphors can be instrumental in examining memories of childhood school days and personal family histories. Metaphors may contain information essential to the growth of early childhood professionals by revealing educational values and principles. The professional identify of pre-service early childhood teachers commencing their journey into teaching is usually not apparent to them. Metaphor assignments encourage novice early childhood education students to frame their professional experiences, dreams, and goals as future teachers. Early childhood teachers who choose rich, complex metaphors for teaching that summarize both the negative and positive sides of the metaphor are well-prepared to meet the challenges of teaching and more likely to be successful than those who do not (Bullough, 1991).

\section{Metaphors for Teaching and Learning}

A wide variety of metaphors proposed over time have provided insight into the professional lives of teachers (Badley \& Van Brummelen, 2012). Often, metaphors serve as models for one's own story and are selected because of their personal appeal. In selecting a metaphor for their professional lives, teachers should consider which values the image represents. For example, does the image reveal the teacher's motivation to increase empathy and sensitivity when caring for children? If a metaphor is to be meaningful, it must convey and illuminate the demands, difficulties, and delights of everyday pedagogical practice (Badley \& Van Brummelen, 2012). Therefore, a beneficial task for early childhood teachers is to seek out pedagogical metaphors that are profound enough to embody their personal and professional identity.

\section{Method}

The purpose of this ethnographic research was to examine metaphors selected by early childhood students that describe their teaching practice and teacher identity. A phenomenological approach was conducted to explore metaphors used in an early childhood education class to increase awareness and introduce first-year early childhood education students to the importance of professional identity, personal teaching, and reflective practice in an early childhood education. The phenomenological approach is grounded on the concept that reality consists of the meaning of experiences by those being studied (Wiersma \& Jurs, 2005). Phenomenological research is holistic (McAllister \& McLaughlin, 1996). Phenomenological research aims to study a whole human system in a natural setting and can provide interpretations of data and events within a context (Lincoln \& Guba, 1985).

\subsection{Procedures}

First, students were prompted and interviewed to think about and list their various roles as future teachers and brainstorm metaphors to convey them. Students discussed the roles and metaphors in small groups, focusing on two questions: (a) What metaphor would you use to represent yourself as an early childhood teacher at this time? And (b) Do you have a vision of the kind of teacher you would like to be? Second, they discussed what implications the metaphors may have for their personal teaching and how they could use them for further reflection. Third, they created pictures of their metaphors bringing the metaphors to "life" by documentation. During the initial discussions, these future educators of young children seemed surprised at the number and complexity of the roles involved in teaching. As a result, the students successfully chose pedagogical metaphors that were profound enough to convey the density of their professional identities and teaching styles at this point in their journey to becoming teachers. Throughout the process, several universal and prototypical themes emerged from their metaphors for teachers and teaching, including guiding, nurturing, molding, transmitting, performing, and scaffolding.

\section{Results}

When early childhood education students internalize the entire reflective process, metaphors mediate how they perceive, interpret, and respond to the ever-changing situations of teacher practice (Badley \& Van Brummelen, 2012). Six categories of metaphors emerged from this study. The categories included teaching as a vocation, teaching as being a change agent, teaching as nurturing, teaching as a wisdom seeker; teaching as a servant leader; and teaching as a professional learner. The themes powerfully convey the way students envisioned themselves as future early childhood teachers, illuminating certain fundamental aspects of early childhood care and the obligations to young children and families. 


\section{Teaching is Enlightening}

In the following metaphor, the education student showed how teaching is showing the way for students:

"Teaching is a light house. It guides the students, but still allows them to make their own way through the world, their sea. The teacher does not chart their course for them; instead, where the shore is and assists them in finding themselves. They have ownership. As teachers, we guide them the way a lighthouse only lights the way, it cannot rescue a sinking ship."

Another metaphor demonstrating teaching as showing the way is as follows:

"Teaching is a GPS. Teachers guide their students to a certain destination every day. Whether their goal is to pass a math test or learn spelling words, it's the teacher's job to get their students to the right place. If the student gets off task or goes in the wrong direction, it's the teacher's job to guide them back to where they need to be."

Another equated teaching to the four seasons: Summer, Fall, Winter, Spring

"I feel that teaching is the four seasons because in the classroom students are always keeping your day interesting and you never know what to expect; however, you can attempt to prepare for happenings that may occur. Being prepared does not always mean that your prediction will be correct, but you can attempt to be ready for any behavior, emotion, or family obstacle with your students. With your students always changing. You have to be able to transition to new classes and students smoothly, but still holding onto the memories that past students have provided you with."

\section{Teaching as Coaching and Facilitating}

One education student wrote, "Teaching is climbing a mountain. You have to help your students climb and succeed by using the tools that are in your classroom."

"I believe a teacher is a tour guide to all the different subject areas. The children in the class are the tourists. It is extremely important that the teacher does everything in his or her power to keep the content interesting and also, more importantly, relevant. The topics that are discussed in a classroom need to follow a set of guidelines. The same is true of a tour guide. Tourists would be lost if the tour guide does not direct them correctly. I cannot think of a better teaching metaphor!"

From climbing a mountain to escorting students as a tour guide, teaching as facilitation as shown in the following metaphor:

"Teaching is a magnifying glass. You must examine the strengths and weaknesses of each child carefully. Once the teacher evaluates, the teacher must support the needs of each student. This metaphor inspires me to be the best teacher I can be, and to help each student with their weaknesses."

\section{Teaching as Shaping the Future}

"Teaching is digging for the treasure buried inside every student. A great teacher will be able to break through obstacles and find the brightness inside their brains."

Another student created the following metaphor for education:

"Knowledge is a steady flame that carries on throughout our lives. The flame of a candle can also be passed from one candle to another. The candle burns steadily and guides us through even the darkest times. I believe knowledge guides us through the hardest times in our lives and offers us a path to follow."

The following example equates teaching and acting:

"I believe teaching is acting. Both require many similar skills. For example, they require a great deal of passion. You must express emotion through what you are doing. They both also require similar technical skills such as good speech and diction. You also must be able to improvise. Sometimes things go wrong on stage such as a missed line or technical malfunction. In the classroom, you may need to change plans or adapt a lesson with very little or no warning. Finally, you need to be able to respond to your audience. Every audience is different; some people respond better to some lines than others. Similarly, children in a classroom will all respond differently. You need to learn to play to your strengths but not be afraid to step outside of your comfort zone."

\section{Teaching as Inscribing New Knowledge}


One student saw the connection between teaching and a guitar:

"The tune of my teaching can be compared to a guitar. Each string represents a characteristic that I will bring to the classroom such as being a good role model, laughter, positivity, enthusiasm, integrity, and eagerness."

Another student created a metaphor for a classroom:

"A classroom is being in a restaurant kitchen. The teacher is the head chef, and the students are their assistants. The teacher gives the student each ingredient, or knowledge that they need to grow successful. All students take what they learn and mix it all together to form who they become. Parents can be their customers. They will see, or get a taste, of what their child is becoming and can determine or not they like what they see."

Another student moved the metaphor from the kitchen to the dance floor:

"Teaching is like dancing, a bunch of wonderful techniques strung together create a beautiful outcome. The children will learn small steps or techniques to get learning started. The more you teach, the more they learn. It culminates with a beautiful performance in the future."

\section{Teaching as Service}

In the following metaphor, a teacher is likened to a composer:

"Every child brings with him or her a unique set of gifts and abilities just as different voices offer varied dynamics, textures, and colors. The teacher, like a composer, takes great care to ensure that each note is positioned in the musical piece (classroom) to high-light the melodious sound it has the potential to make. When every child is set up to succeed, when the classroom is filled with the warm laughter of children glowing in their confidence and creativity, a true musical masterpiece is born."

Another metaphor cites the teacher as gardener:

"A teacher is a gardener who feeds and nourishes the seeds to let them grow and blossom. Teaching is a process that takes time and a lot of care. The students start off as seeds and as they are nurtured and given knowledge, they will grow into beautiful flowers."

\section{Teaching as a Catalyst for Change}

"Teaching is a puzzle. All of the pieces are shaped very differently, but together they create a beautiful picture."

"Teaching is a baseball game. In teaching and baseball, the student is not only learning how to be a good hitter, a good pitcher, good at math, or good at spelling. Instead, the student is learning how to be a great person, how to problem solve, and figure things out yourself, how to do things the right way, be kind to others, be passionate about what you and how to reach your full potential. That is the ultimate goal of every play and teacher, to reach your full potential and have your students on the right track to reaching others."

"Teaching is a fingerprint. Everyone has them. Their styles differ, but they all serve the same purpose. Each person's fingerprints are unique to the individual just as the experiences given or received in the classroom. Teaching allows for self-discovery and identification similar to the way each fingerprint identifies an individual. Both teaching and fingerprints are a common factor with humanity that unites people together."

\section{Figure 1. Categories of Teaching Metaphors}

\section{Implications for Teaching Practices}

Metaphors have the potential to enrich early childhood students' thinking and practice, thereby enriching student learning (Badley \& Van Brummelen, 2012). The responses from early childhood students regarding metaphors for teaching strengthened professional identity as future early childhood professionals, uplifted their passion for becoming early childhood teachers, and introduced the importance of becoming a reflective early childhood practitioner. In addition, creating metaphors assisted with recognizing certain dispositions, realities, joys, and demands of teaching. The research concluded that early childhood students readily explore metaphors to describe their identity as future teachers and practice. Metaphors provided opportunities for students to consider looking at teaching through a variety of lenses. What emerged were new voices and possibilities as future early childhood teachers. In addition, creating metaphors and having the opportunity to share them were useful in associating thought and action in conversations with colleagues. 
Metaphors connected new patterns regarding pedagogy and promoted a community filled with inspiration, motivation, dreams, and enthusiasm in which students were comfortable proclaiming their personal visions with class members.

\section{Discussion}

Teaching is a two-sided human activity: On each side are human beings, whole people with their own unique thoughts, hopes, dreams, inspiration, needs, experiences, and priorities (Ayers, 2001). The use of metaphors can offer early childhood students an engaging line of inquiry for learning new information, concepts and skills, and defining experiences in order to achieve deeper meaning about the life of an early childhood teacher; furthermore, metaphors serve as a supportive instructional tool for conversations regarding professional identity, teaching, and the importance of becoming a reflective practitioner. Metaphors can motivate early childhood students as a springboard and foundation to recognize their individual strengths, develop leadership skills as future visionaries in early childhood, and inspire passionate, and caring professional teachers for our next generation of youngest learners. An important consideration for future research would be studying metaphors to show the change that may occur in early childhood students' beliefs and attitudes at the conclusion of their professional and education studies and throughout their first three years of teaching. With this in mind, the use of metaphors should be recognized as an important teaching tool for teacher preparation programs, educator professional development workshops, and practitioners in the field of education.

\section{References}

Ayers, W. (2001). To teach: The journey of a teacher. New York, NY: Teachers College Press.

Badley, K., \& Van Brummelen, H. (2012). Metaphors we teach by: How metaphors shape what we do in classrooms. Eugene, OR: Wipf \& Stock.

Barbour, N., \& Lash, M. (2009). The professional development of teachers of young children. In S. Feeney, A. Galper, \& C. Seefeldt (Eds.), Continuing issues in early childhood education (pp. 158-183). Upper Saddle River, NJ: Pearson.

Black, A. L., \& Halliwell, G. (2000). Accessing practical knowledge: How? Why? Teaching and Teaching Education, 19, 277-290.

Bullough, R. V. (1991). Exploring personal teaching metaphors in preservice teacher education. Journal of Teacher Education, 42, 43-51. https://doi.org/10.1177/002248719104200107

Efron, S., \& Joseph, P. B. (2001). Reflections in a mirror: Metaphors of teachers and teaching. In P. B. Joseph \& G. E. Burnaford (Eds.), Images of schoolteachers in America (pp. 75-91), Mahwah, NJ: Lawrence Erlbaum.

Gillis, C., \& Johnson, C. L. (2002). Metaphor as renewal: Re-imaging our professional selves. The English Journal, 91, 37-43. https://doi.org/10.2307/821814

Hammerness, K. (2006). Seeing through teachers' eyes: Professional ideals and classroom practice. New York, NY: Teachers College Press.

Hoban, G. (2000). Using a reflective framework to study teaching-learning relationships. Reflective Practice, 1, 165-182. https://doi.org/10.1080/713693148

Holt-Reynolds, D. (1992). The personal history-based beliefs as relevant prior knowledge in coursework. American Educational Research Journal, 29(2), 325-349. https://doi.org/10.3102/00028312029002325

Inbar, D. (1996). The free educational prison: Metaphors and images. Educational Research, 28, 77-92. https://doi.org/10.1080/0013188960380106

Kesen, A. (2013). What lies beneath teacher beliefs? A study on metaphoric perceptions. International Journal of Human Sciences, 10, 1491-1502.

Lakoff, G., \& Johnson, W. (1980). Metaphors we live by. Chicago, IL: Chicago University Press.

Lincoln, Y., \& Guba, E. (1985). Naturalistic Enquiry. Beverly Hill, CA: Sage. https://doi.org/10.1016/0147-1767(85)90062-8

Mac Cormac, E. R. (1985). A cognitive theory of metaphor. Cambridge, MA: MIT Press.

Martinez, M. A., Sauleda, N., \& Huber, G. L. (2001). Metaphors as blueprints of thinking about teaching and learning. Teaching and Teacher Education, 17, 965-977. https://doi.org/10.1016/S0742-051X(01)00043-9

Massengill, S. D., \& Mahlios, M. (2008). Pre-service teachers' metaphors of teaching and literacy. Reading Psychology, 29(1), 31-60. https://doi.org/10.1080/02702710701568397

McAllister, M., \& McLaughlin, D. (1996). Teaching metaphors of student nurses. Journal of Advanced Nursing, 23, 
1110-1120. https://doi.org/10.1046/j.1365-2648.1996.01416.x

Milton, C. L. (2009). Common metaphors in nursing ethics. Nursing Science Quarterly, 22(4), 318-322. https://doi.org/10.1177/0894318409344770

Noe, L. R. (2007). What's it like? Making meaning with metaphors. Young Children, 62(4), 30-31.

Oxford, R. L., Tomlinson, S., Barcelos, A., Harrington, C., Lavine, R. Z., Saleh, A., el al. (1998). Clashing metaphors about classroom teachers: Toward a systematic typology for the language teaching field. System, 26, 3-50. https://doi.org/10.1016/S0346-251X(97)00071-7

Palmer, P. J. (1998). The courage to teach: Exploring the inner landscape of a teacher's life. San Francisco: CA: Josssey-Bass.

Perry, C., \& Cooper, M. (2001). Metaphors are good mirrors: Reflecting on change for teacher educators. Reflective Practice, 2, 41-52. https://doi.org/10.1080/14623940120035514

Pinnegar, S., Mangelson, J., Reed, M., \& Groves, S. (2011). Exploring preservice teachers' metaphor plotlines, 27, 639-647. https://doi.org/10.1016/j.tate.2010.11.002

Ryan, S., \& Whitebrook, M. (2012). "More than teachers: The early care and education workforce." In R. C. Pianta, W.S. Barnett, L. M. Justice, \& S. M. Sheridan (Eds.), Handbook of Early Childhood education (Chapter 5, pp. 92-110). Guilford.

Thomas, L., \& Beauchamp, C. (2011). Understanding new teachers' professional identities through metaphor. Teaching and Teacher Education, 17, 762-769. https://doi.org/10.1016/j.tate.2010.12.007

Wiersma, W., \& Jurs, S. G. (2005). Research methods in education: An introduction. Boston, MA: Pearson.

Zhao, H., Coombs, S., \& Zhou, X. (2010). Developing professional knowledge about teachers through metaphor research: Facilitating a process of change. Teacher Development, 14, 381-395. https://doi.org/10.1080/13664530.2010.504024

\section{Copyrights}

Copyright for this article is retained by the author(s), with first publication rights granted to the journal.

This is an open-access article distributed under the terms and conditions of the Creative Commons Attribution license which permits unrestricted use, distribution, and reproduction in any medium, provided the original work is properly cited. 